\title{
Science at home: parents' need for support to implement video-based online science club with young children
}

\author{
Jenni Vartiainen ${ }^{1}$ and Maija Aksela ${ }^{2}$ \\ ${ }^{1}$ Department of Education, University of Helsinki, Finland \\ 2 LUMA Centre Finland, University of Helsinki, Finland
}

\begin{abstract}
Homes have remarkable possibilities to act as science learning environments for young children ( $3-6$ years old). This qualitative case study investigated what kind of support parents need to do online science activities with their children at home. Data consisted of parent's theme interviews $(n=7)$. As a main result, a model of parents' need for support was produced. The model contains three dimensions: 1 ) the affective dimension, 2) the knowledge and skills dimension and 3) the organizational dimension. Parents' own affective experiences, organization of the experiments and finding time to do experiments are important factors to consider, when looking at parents' willingness to engage in science activities with their children. The parents might not necessarily be content with only the child's interest in experimenting as a reason to carry out science activities at home, instead they need to be interested and engaged in activities themselves.
\end{abstract}

Keywords: early childhood education, video-based online science club, non-formal education, inquiry

\author{
Article details \\ LUMAT General Issue \\ Vol 7 No 1 (2018), 59-78 \\ Received 5 June 2018 \\ Accepted 26 February 2019 \\ Published 26 February 2019 \\ Pages: 20 \\ References: 46 \\ Contact: \\ jenni.vartiainen@helsinki.fi \\ https://doi.org/10.31129/ \\ LUMAT.7.1.349
}

\section{Introduction}

The positive effects of an early introduction of science to young children have been acknowledged in earlier studies: it can support the development of the child's interest in, motivation and positive attitudes towards science (Mantzicopoulos, Patrick \& Samarapungavan, 2008; Nayfeld, Brenneman, \& Gelman, 2011) and thus, improve the later learning outcomes (Guo, Wang, Hall,, Breit-Smith, \& Busch, 2016; Leuchter, Saalbach \& Hardy, 2014; Spektor-Levy, Baruch \& Mevarech, 2013; Maltese \& Tai, 2010). Inquiry-based learning is a widely used approach in science education at all levels of science, including young children (Samarapungavan, Patrick \& Mantzicopoulos, 2011; Minner, Levy \& Century, 2010; Peterson \& French, 2008). The learning of science process skills and thinking skills are important goals for young children's inquiry-based science education (Kuhn, Black, Keselman \& Kaplan, 2000). A child explores, wonders and makes observations of the world around them all the time. It is important for children, with the guidance of an adult, to be able to become familiar with science phenomena occurring in their environment. (Eshack \& Fried, 2005). It has been argued that various scientific concepts can be successfully 
introduced to children in early years (Kalogiannakis \& Nirgianaki, 2018; Ampartzaki \& Kalogiannakis, 2016).

Numerous research has shown that the home context has a major significance in children's education. Parents' attitudes have an effect on the development of child's future attitude, motivation and interest towards science (Mantzicoupoulos, Patrick \& Samarapungavan, 2013; Stylianides \& Stylianides, 2011; Crawford, Heaton, Heslop \& Kixmiller, 2009; Solomon, 2003). Especially during the early years, the parents' participatory role is important for creating positive experiences (Kaya \& Lundeen, 2010). The parents also have an influence on what kinds of non-formal and informal possibilities there are for a child to experience science, for example what kinds of books are available at home and are children offered with possibilities to experience science in non-formal settings, as science clubs, science events or science centres. However, parents have low feeling of competence to introduce science for children in non-formal way in home contexts and they do not necessarily even recognize that science is something that can be teached to children outside formal schooling system (McClure et al., 2017). Further, parents do not feel that science would be high on their lists, when speaking of knowledge and skills that they would want their children to learn. From academic skills, parents would more likely look forward to the development of their children's linguistic, motoric and mathematical skills (Saçkes, 2014). Different forms of support should be developed for parents' attitudes and understanding of the meaning of science in everyday circumstances, so that children would have a chance to get familiar with science through different activities at home or as a hobby.

With the development of technology, the meaning of home as a learning environment has further increased (Plowman, Stephen \& McPake, 2010; Palaiologou, 2014). Children learn for example reading and mathematics through different digital toys, mobile applications and the internet. There is a gap in research on young children's non-formal science activities in general (Young, Ortiz \& Young, 2017) and especially on how digital technology can be used to promote young children's possibilities to do science at home environments. This study narrows this gap by studying how parents feel like to participate in video-based online science club with young children at homes. For the research purposes the video-based online science club learning environment with video instructions was built leaning on earlier research on young children's science clubs (Vartiainen \& Aksela, 2013). In more 
detail, the case study (Yin, 2009), investigates what kind of support parents need, when participating in a video-based online science club at home with a child.

\section{Home as a non-formal learning environment}

Home is generally seen as a place for informal learning. Informal learning is neither structured nor target-oriented and the learners are responsible for their learning. This occurs in everyday situations outside educational institutions (Eshach, 2007). In informal setting scientific knowledge is acquired through internet, social media, television, books and newspapers, for instance (Schäfer et al. 2018). In addition to an informal learning environment, home can also act as an encouraging non-formal learning environment for science (Shymansky et al., 2000; Solomon, 2003; Reinhart et al., 2016). Usually, non-formal learning environments are facilitated and hold some often skill-related learning targets, but there are volunteer to participate in, like science clubs, camps, museums, zoos, planetariums, science centers and companies (Eschach, 2007). In this research we define that video-based online science club is a non-formal learning environment although it most often it is put into practice at home.

Non-formal science learning environments can support a child's learning of science, the development of the skill of wondering, an increase in interest, excitement and motivation towards science when done well (Young, Ortis \& Young, 2017). However, not all science activities or non-formal learning environments have positive effects. Successful non-formal science education requires careful design on social focus and widening the scope of skills to be learned from science to social skills as well. Solomon (2003) studied families with children between ages $5-10$, for whom hands-on science activities were offered by the school. The families were given instructions for the activities and the tools needed could be found from home, among ordinary household tools. As a result, both the children and the parents enjoyed doing the activities together. Also, Shymansky et al. (2000) reported that as a consequence of hands-on science activities done at home both children and parents found it an enjoyable way to spend time together, while doing something useful.

Reinhart et al. (2016) researched inquiry-based science activities occurring at home. In their model, families were sent science packages, which contained the inquiry activity and necessary tools. The target group was from kindergarteners to 3 rd graders. It was observed that the most significant challenge in inquiry-based science 
education happening at home was the way parents instructed the children and the nature of questions they asked. To address this, it was proposed that the support and training aimed at parents should be planned in cooperation with schools. In the science packages, the inquiry activity was reported by filling a form. The children found that the written reporting was quite boring, and it reminded them too much of homework (Reinhart et al., 2016). Reporting non-formal activities in the form of videos or pictures might be a more engaging way for children to communicate the results and the process of the science activity than with the written form.

Essential in science activities done in the home environment is that all needed tools should be found at home (Solomon, 2003). Parents need instructions and ready materials to be able to instruct the child pedagogically and to explain the inquiry activity (Eshach, 2007). Parents especially need instructions on how to do open inquiry with a child. They do not give enough time for the child to ponder on the questions and they pressurize the child to give out a specific answer, defined as correct by the parents (Reinhart et al., 2016).

In prior researches, non-formal science education occurring at home has been connected to either science packages sent home or those that are received from schools (Shymansky et al., 2000; Reinhart et al., 2016). Until now, there has not been a significant amount of research on how young children's participation in science activities at homes could be supported with the help of digital tools. Web pages that offer inquiry activities done at home exist, but they do not offer interaction from the point of view of reporting research or of communication, nor do they give support in instructing children. Natural way for young children is to use digital media as enlargements of their activities. Children are more often active users of digital media than passive consumers (Plowman, McPake \& Stephen, 2010). Thus, video-based online science club activities have great potential to serve as a spark to encourage children to do hands-on activities at homes with parents.

\section{Videos as a tool for science instruction}

The advantages of videos in education have been widely acknowledged. They are not bound to a specific time or place, they allow visualization of authentic targets and they make it possible for a learner to be able to return back to the contents. Videos made by the children themselves support an inquiry-based approach (Skoretz \& Cottle, 2011). Exploiting videos in inquiry-based science education works well with 
children, who have difficulties with reading and writing or who do not yet know how to read and write. Videos offer a chance for young children to get information and to express themselves freely (Bull \& Kajder, 2004).

Even young children use daily digital devices - most often tablet and smartphones - to play, for entertainment and to use fun educative applications or in other words edutainment applications (Chaudron et al. 2015). Parents have dichotomy attitudes in children's digital media use: on the other hand they see the advantages it can have on children's informal or non-formal learning but at the same time they are worried about the safety issues, like inappropriate content, overspending accidental time with devices and the issues that digital content use might have on children's social lifes (Kumpulainen \& Gillen, 2017).

For young children digital media use can give wide possibilities to express themselves while verbal communication skills are still developing. Pictures and videos are examples of pedagogically effective ways for children to participate in communication. A video produced by the child is a suitable way to communicate the stages and results of the accomplished inquiry task. In the process of producing a video, a child's feelings and thinking are activated (Robert-Holmes, 2013). In children's science education, it is important that an activity allows the child to be able to activate functionally, cognitively and affectively (Inan \& Inan, 2015). The videos produced by children tell the other viewers about the child's research process and results. Equally important is that from the point of view of learning and feelings, a child can return back to the video, where they act (Robert-Holmes, 2013). RobertHolmes (2013) states that children enjoy watching their own videos over and over again. While watching the video, children can re-live their experiments, pose the questions, elaborate their conclusions and pay attention to the details they might have missed during the experimenting in real life.

A challenge in video-based instructions is the lack of interaction between the instructor and a student (Kim \& Thayne, 2015). However, the feeling of interaction between the media consumer and the content through using parasocial interaction (Glaser et al., 2009). Parasocial interaction is an effect of narrativeness, and it can be created especially, when a person in a video speaks directly to the viewer. However, through the parasocial interaction transmitted by a video, it is not possible to give a child scaffolding that they need in the science activities, therefore interaction occurring between a child and a parent during a science activity is essential. 


\section{Context}

This research was conducted in the context of a video-based online science club. The video-based online science club operates in the web environment and its aim is to support children's participation in science activities at home. The club was free of charge.

Before a video-based online science club begins, a list of tools and necessary materials are sent by email to the parents. The video-based online science club is a 6-week entity. A new instruction video appeared on Thursday afternoons. Families were able to send reports on the completed inquiry activities either in the form of pictures or videos. Children were rewarded, for completing the club entity and reporting about it, with a diploma and a surprise gift.

The instruction video consisted of three parts: (i) motivating the child on the activity and connecting it to the child's earlier experiences, (ii) instructing the child on performing the activity and (iii) encouraging the child to report observations, results and questions afterwards. The instruction video was designed to have a colorful set design. A video-based online science club instructor performed on the video. Seeing the instructor on the video and directing the speech directly towards the child creates parasocial interaction between the instructor and the child. The length of each instruction video was approximately 3-6 minutes. The science activities were grounded on a playful approach: the instruction videos contain stories (Bulunuz, 2013) and puppets (Simon, Naylor, Keogh, Maloney \& Dowing, 2008) to motivate children towards experimenting.

The video-based online science club included science experiments on 1) floating and sinking 2) surface tension 3) sound 4) growing speed of a plant 5) tornados, and 6) volcanos. These themes were chosen according to researches on themes that children are usually interested in (Baram-Tsabari, Sethi \& Yarden, 2006).

\section{Aim and methodology}

The aim of this research was to describe, what kind of support parents need in engaging in science activities at home together with the child. This research focus on which factors have an effect on whether a parent offers child possibilities to carry out science experiments at home. 
Research was carried out as a qualitative case study (Yin, 2009). The participants in this research was a group of parents ( $n=7 ; 2$ male, 5 female), who took part in a video-based online science club with their child or children. Data was collected in autumn 2015 by a theme interview in phone (Hirsjärvi \& Hurme, 2008; Burke \& Miller, 2001). 335 families or other groups had registered for the video-based online science club. The interviewees were chosen so that they had completed at least five science activities at home and reported activities in the form of pictures or videos. Reported pictures and videos were used as stimulated recall material. All the families who had sent at least five reports $(n=27)$, received an invitation to an interview. All the people, who answered in the affirmative $(n=7)$, were chosen to participate in the interview. The interviewees came from all around the country, which then had an effect on the interview method chosen. It was seen that a telephone interview would offer the necessary information.

The interviewees were approached first by email, where the aim of the interview was explained and the stimulated recall material was introduced. The interviewee was given the chance to choose a proper time for the interview. By doing this, it ensured that the interviewee has enough time to prepare for the interview and time to think through their answers, and also the interviewee is in a situation, where they are in a calm environment. The telephone interviews were recorded. The interview was piloted and had been improved twice before the actual telephone interviews. Pilots gave feedback about formatting of questions and the order of questions which were improver for actual interview. The interview questions included background questions about how families found the online club, have a parent done science activities with a child/children before the online club and what kind of attitudes parent have towards science. Parent was asked to reflect on stimulated recall material sent for him/her beforehand and describe the experimenting situation starting from the preparations. The clarifying questions were posed to gain deeper understanding on parent's ideas. Parents were also asked to reflect on the challenges they met and how did they feel children benefit from the participation in video-based online science club.

Most of the parents stated that they have a positive attitude towards science. The parents felt that nature itself and working in nature was something really close to them. A part of them worked in professions that were applicable to science and technology. There were also some parents, who experienced that science had been at least among some subjects, quite undesirable to them when they went to school. 
To enhance the reliability, the results were introduced to all the interviewees to make sure that inferences made from the data were as interviewees thought they had told. No one found misinterpretations. We would like to underscore that the research group is small and therefore results are directing and benefit when this kind of online learning environments are developed further.

\section{Data analysis}

The interview transcriptions were analyzed by qualitative data driven content analysis (Schreier, 2014). The data analysis was started with a systematic open coding. Each sentence was coded in order to describe the contents of the sentence as described by the interviewee. As an example, a parent's sentence: 'The children were actually really enthusiastic of this', was marked with a code Child was enthusiastic. After the open analysis, axial coding was performed by joining similar categories and then describing these newly formed categories. Axial coding occurred around three axels arising from the data: the possibilities experienced by the parents, the challenges experienced by the parents and the role of a parent. For example, from the codes Child enthusiastic, Child interested, Child thinks is fun, a new category was starting to form which was named as A child's affective experiences. Then the main categories of the data were located. Selective coding was performed between the main categories in order to find out which factors the parents experience as challenging, while doing science activities with children. The example of coding is presented in Table 1.

Table 1. An example of a coding scheme.

\begin{tabular}{|l|l|l|l|l|}
\hline A parent's utterance & Code & Sub-category & Main category & Core category \\
\hline $\begin{array}{l}\text { But there is also some clear } \\
\text { thing here in that there is a } \\
\text { timetable and there is a } \\
\text { contact person. }\end{array}$ & Timetable & $\begin{array}{l}\text { The structure of } \\
\text { operations }\end{array}$ & $\begin{array}{l}\text { Support for } \\
\text { organizing } \\
\text { activities }\end{array}$ & $\begin{array}{l}\text { The parent's } \\
\text { need for support } \\
\text { on three areas }\end{array}$ \\
$\begin{array}{l}\text { Well, of course a parent is } \\
\text { needed in how things are }\end{array}$ & Arrangements & $\begin{array}{l}\text { The parent's } \\
\text { preparations } \\
\text { /arrangements } \\
\text { for the } \\
\text { implementation } \\
\text { of an activity }\end{array}$ & & \\
\hline
\end{tabular}




\begin{tabular}{|c|c|c|c|c|}
\hline $\begin{array}{l}\text { I prepared the tools myself, } \\
\text { the things that we needed } \\
\text { in the experiments, such as } \\
\text { bowls, water and oranges. }\end{array}$ & $\begin{array}{l}\text { The parent } \\
\text { organizes }\end{array}$ & & & \\
\hline $\begin{array}{l}\text { Or then I was thinking that } \\
\text { in which way (...) what } \\
\text { would be a suitable bowl } \\
\text { that would not tip over } \\
\text { easily }\end{array}$ & $\begin{array}{l}\text { The parent } \\
\text { plans the } \\
\text { implementation }\end{array}$ & & & \\
\hline $\begin{array}{l}\text { I myself start wondering, } \\
\text { why is it so that styrofoam } \\
\text { is a kind of a material that } \\
\text { floats. }\end{array}$ & $\begin{array}{l}\text { A parent's need } \\
\text { for background } \\
\text { knowledge }\end{array}$ & \multirow[t]{2}{*}{$\begin{array}{l}\text { Parent's } \\
\text { understanding } \\
\text { the science of } \\
\text { phenomenon }\end{array}$} & \multirow[t]{4}{*}{$\begin{array}{l}\text { The support on } \\
\text { knowledge and } \\
\text { skills }\end{array}$} & \\
\hline $\begin{array}{l}\text { At times, it has been } \\
\text { necessary to find } \\
\text { background information for } \\
\text { the experiments, so to be } \\
\text { able to explain yourself a } \\
\text { self-evident truth. }\end{array}$ & $\begin{array}{l}\text { A parent's need } \\
\text { for knowledge } \\
\text { background } \\
\text { knowledge }\end{array}$ & & & \\
\hline $\begin{array}{l}\text { The parent makes sure that } \\
\text { the instructions are being } \\
\text { followed and that the child } \\
\text { gets to do as much as } \\
\text { possible by } \\
\text { themselves/independently. }\end{array}$ & $\begin{array}{l}\text { Guiding the } \\
\text { child's work }\end{array}$ & \multirow[t]{2}{*}{$\begin{array}{l}\text { The parent } \\
\text { instructs the } \\
\text { child }\end{array}$} & & \\
\hline $\begin{array}{l}\text { At times, it is so } \\
\text { complicated to come up } \\
\text { with a way to explain self- } \\
\text { evident truths to the child. }\end{array}$ & $\begin{array}{l}\text { Explaining } \\
\text { phenomenon to } \\
\text { the child }\end{array}$ & & & \\
\hline $\begin{array}{l}\text { But of course it requires } \\
\text { effort from the parent and I } \\
\text { don't know if the parents } \\
\text { are interested enough in } \\
\text { natural sciences that they } \\
\text { have the energy to make } \\
\text { preparations for the } \\
\text { experiments. }\end{array}$ & $\begin{array}{l}\text { The parent's } \\
\text { efforts }\end{array}$ & \multirow[t]{2}{*}{$\begin{array}{l}\text { The parent's } \\
\text { own interest }\end{array}$} & \multirow[t]{2}{*}{$\begin{array}{l}\text { The parent's } \\
\text { affective } \\
\text { support }\end{array}$} & \\
\hline $\begin{array}{l}\text { We registered for a follow- } \\
\text { up club as well, but then we } \\
\text { were not able to do the } \\
\text { assignments anymore. So } \\
\text { that was probably why I lost } \\
\text { my interest. }\end{array}$ & $\begin{array}{l}\text { The parent is } \\
\text { not interested } \\
\text { anymore }\end{array}$ & & & \\
\hline
\end{tabular}




\section{Results}

This research produced a model that describes what kind of support parents need in the realization of inquiry-based science activities occurring at home. Three factors have an effect on whether or not the parent completes the activities of a video-based online science club together with a child. These three factors are: the affective factor, 2) the knowledge and skills factor and 3) the organizational factor. In order for the parents to complete activities at home together with the child, the online learning environment should itself offer support to them on all of these above mentioned areas.

\subsection{The need for support on parents' affective experience}

The interviewees felt that the activity of the parent is in a key role so that the videobased online science club activities would be completed at home. Only the child's excitement and interest were not necessarily seen as an adequate reason in order for the parent to organize a time slot for doing the activities, if there were issues in the other areas.

\footnotetext{
"We registered for a follow-up club as well, but then we were not able to do the assignments anymore. So that was probably why I lost my interest. Maybe that first assignment, which was given in this follow-up club was not ... in a way ... didn't feel like suitable or ... didn't feel like easy, so that we could have been able to understand what was the point. And then in addition, the challenge of uploading the videos, so in principle, yes I should have been able to get through this, but, the child would have been quite enthusiastic. The child had not in any case reached his/her limit." (Parent 6)
}

In order for a parent to participate in a video-based online science club with their child and to make it possible to do activities, the parent should also be made motivated and interested. The parent should be able to explain the significance of the assignments both from the point of view of the child and the parent.

"But of course it demands a kind of an effort from the parent and I'm not sure, if all the parents have such a great interest towards sciences that they would be able to make specific preparations for the assignment for the child." (Parent 6)

The parents' positive experiences on science had an effect on the parents' will to complete video-based online science club activities at home with a child. On the other hand, the parents' own bad experiences in science encouraged them to keep on. In 
these situations, they wanted to offer the child positive experiences and a soft landing on sciences, so that the children would not have challenges with it in school.

"But then chemistry and math were not for me ... but at this moment I try to look at this positively, because there are many learners in the family. So I don't want to transfer my own attitude, repulsiveness, to them." (Parent 5)

The children's positive experiences acquired from doing activities were affected by the parents' affective experiences. All the interviewees highlighted the possibilities of a video-based online science club: a child's enthusiasm and positive experiences.

"The best of this was that the children had fun. They got a positive experience from the fact that it is fun to do these kinds of experiments and to research. The best in this was the positive experience" (Parent 7)

"So that in a way they got to try, and to get sparked up about these things and to come up with questions and to ponder and discuss things, yes, this kind of doing together was just the best." (Parent 2)

In addition to supporting the enthusiasm and interests, the parents also observed a wider dimension that is subservient to a child's future. A performance diploma received from the club, would be able to help the child in a concrete way for example when applying to science-oriented schools.

\begin{abstract}
"This gives little hope for the fact that when we're thinking about this more widely, how we could get this society's resources into use and like these, these adolescents to grow, who are able to do something useful and significant in the society, then I believe that it starts from those really young that we would be able to create enthusiasm and interest, so that in a way this gave me some reinforcement that the young have the interest in themselves that we should just be able to feed it." (Parent 3)
\end{abstract}

\title{
7.2 The need for support on knowledge and pedagogical skills
}

The parent should be offered content information of the background of the phenomena and pedagogical information on how the specific phenomenon would be presented and to encourage the child to think for themselves in the context of a specific activity. The parents instructed the child spontaneously with questions, requests and with encouraging towards trying. They aimed to create the experimenting into such that the child would themselves come up with observations and would get an Aha moment. 
"I was asking quite leading questions and I aimed at ... like letting the child to come up with different observations and not giving the answers myself." (Parent 6)

"So that somehow a child does things quite easily, this was nice, but maybe they would not independently start pondering, why this or that happened. So here we are ... There, I think, a parent's role is important that they ask did you understand, what happened there and why could it be so and then we go over what we learned there. So these discussions have often led to many other interesting discussions. But in a way of different phenomena." (Parent 3)

The parents wish that they would be given more support on how the phenomena occurring in the activities can be explained to the child. They also wished for more information about that for themselves. Some parents prepared for the research by finding out the backgrounds of the phenomenon. They told that they learned quite a lot by doing this. The parents also resorted to data retrieval, when some part of the activity did not go as planned.

"And then to explain why: (...) why styrofoam floats, why like (...), why an orange floats when it is not peeled and sinks when it is. And in these, on the other hand, were some, well (...), challenges every now and then, like you start thinking yourself, why is it so, why is styrofoam a kind of a material that floats. At times, it has been necessary to find background information for the experiments, so to be able to explain yourself a self-evident truth.” (Parent 1)

In addition, the parents appreciated the fact that the activities of the club were built as pedagogically ready, a motivation and a context had been described for the activities. Some of the parents had information about the phenomena themselves, but they found it quite challenging for themselves to think of a way to present it to the child.

"I think that this was really good. I would not have even thought of this, to experiment these things even if I had had information about them." (Parent 8)

\subsection{The need for support on organizing activities}

The club's structured and outside organized structure was seen as positive, even necessary, so that it was possible to take part in a video-based online science club at home. The parents felt that they would not have done activities regularly, if the reporting would not have had a deadline. Directions for the experiments done at home could be found from elsewhere on the internet both in the form of videos and text, but 
parents felt that a structured model, where a contact person exists, encourages to do the activities regularly and in a persevering way.

\begin{abstract}
"Well this thing is really fantastic. In a way, that it could be on the internet just as it is, that someone had put it up there in the early 21st Century and that we would do assignments there and a message would be sent to some robot that now we have completed an assignment and then we can print the diploma from there, but there is also some clear thing here in that there is a timetable and there is a contact person." (Parent 1)
\end{abstract}

The daily life for families with children is often busy. All the interviewees highlighted that a video-based online science club's possibility is the fact that the family can themselves define the time and place, when there is a good moment to do these activities, taking into consideration the family's other plans and children's level of alertness.

\begin{abstract}
"Well I think of this as fantastic, since I indeed have three small children, then just the physical effort of taking the children to their hobbies, well ... It [activity of the club] can be done when it best suits us, it isn't connected to a specific time or place, it is really great ... and that children are in such a state of alertness that they are not tired or really interested in something else, so that they are able to focus on the activity." (Parent 2)
\end{abstract}

The fact that the club is not connected to a specific time or place is seen as a possibility in spreading the video-based online science club operations also outside Finnish borders.

"Well I think that it is great that this is so much easier to spread elsewhere compared to one where you would have to physically go to a certain place. ... This could be used, not only at home, but also in afternoon clubs or in kindergarten or, or elsewhere and then there's the fact that it's not, it's not connected to a specific time and place." (Parent 3)

"And then I think there is also this kind of a question on equality, that we could think that in the countryside, where no such clubs are held, they are also able to take part or even people abroad can take part in a club with their own language. Yes, there are many possibilities, absolutely a good thing." (Parent 7)

\title{
7.4 The challenges of a video-based online science club
}

An online learning environment was experienced technologically as dysfunctional in many ways. The following caused challenges: 1) the obscure structure of the website, 2) the slowness or inactivity of data transfer, 3) the indistinctness of the reporting form of the completed activity 4) the poor quality of the voices in the instruction 
videos and of set design and 5) a worry for the preservation of the child's protection of identity. The website was experienced as muddled and dysfunctional for a videobased online science club operation.

"If the aim was that this would be used more, then it should be distinctly easier, more down-to-earth. There are many kinds of technological barriers, because of which it is not easy to use, as is not the concept used at this moment." (Parent 6)

The uploading of the report videos created by the parents and the children was slow and often the videos could not be sent.

" Then the video got so big that we were not able to upload it there at all." (Parent 4)

"But the thing that was the most annoying was the fact that the most difficult process was to put the video on the internet, it was really not easy. I started losing interest at this point in this bustle." (Parent 6)

Also the instruction videos had some technological challenges. The volumes of the sounds were not in the same level in all parts of the video, which then caused challenges.

"The only thing that was challenging, well was the audio in these videos, since the theme music was so loud and then when I turned the volume down, we could not hear anything when a person started talking on the video.” (Parent 7)

A child's protection of identity was also thought of as a challenge, since picture and video material were sent into a fully open website.

"The situation was quite sensitive, because pictures of the child taken at home were sent on the web." (Parent 2)

\subsection{A parent's role in video-based online science club activities}

Parents' interviews showed that activities are done together with the child, when they have the day off. The realization starts from the parents' initiative, but the children answer to this initiative positively and enthusiastically. The parent has watched the instruction video beforehand, so that they are able to prepare for the experiment on behalf of tools and other parts of the experiment. The child and the parent watch the instruction video again together. The video is also watched again during the activity, if they want to check some parts of the instructions. The children took part in the 
reporting of the activities together with the parent by choosing the pictures or videos, which would be sent to the video-based online science club. The parents didn't report that the children would have themselves taken part actively in the reporting. They chose the pictures and videos that were sent together, but the parents took care of the filing and of the handling of the report material without the participation of the child. The data analysis of narrative interviews proved that children spontaneously returned to results of prior inquiries in new contexts, where the specific phenomenon could be observed.

"The girl was then interested, interested in that later, after a long time of about few months, we have sometimes pondered on the floating experiment and she/he was then quite surprised that such a large item as a piece of wood was floating, floating there. However we have returned to that after such a long time, to the results of the experiment." (Parent 2)

"And then exactly the same phenomenon here as well that the idea of surface tension stayed in the background. This came up in the discussions with the older child that when we were by a pond and we saw some water fleas or spiders making their way on top of the surface, we were just wondering there and we made a connection between the thing that we had been testing, the phenomenon could then be observed in the nature." (Parent 6)

The results pointed out that the need for an instruction dealing with a non-formal learning situation occurring at home, has two different sides. The parents told that they had to direct the child with questions, requests, by giving them an open invitation and by dividing the experiment into parts. From the parents' descriptions of the inquiry situation, it could be seen that the children were instructed and supported affectively by the parents. On the other hand, parents still feel that they need directions themselves on how to instruct a child. The parents need both content knowledge of the phenomena as well as pedagogical support on how to explain and introduce children to scientific phenomena.

\section{Conclusions}

Parents need support on three different areas in order to take part in a video-based online science club at home with their children. According to this research, they need support in understanding scientific phenomena and as well in instructing children. Similar results have been pointed out in earlier studies (Eshach, 2007). In addition to that, this study found that the parents' own affective experiences as well as organization of the experiments and finding time to do experimenting are important 
factors to consider when looking at parents' willingness to engage in science activities with the children. The parents might not necessarily be content with only the child's eagerness and interest towards experiments as a reason to carry out the video-based online science club activities at home, instead they need to be interested and enthusiastic by themselves about activities and they need to be able to maintain them. It is common that parents are first enthusiastic about doing science activities with the child, but they lose their interest quickly (Solomon, 2003). The children did not take part in the documentation of inquiry nor in the documentation of results or in the reporting of the results. The child's participation in the documentation of the activity and in presenting the results is an essential part of the process of inquiry-based science education (Minner et al., 2010). The technological realization of the learning environment was seen as quite poor. Especially, the challenges in uploading pictures and videos made it difficult to use.

On the grounds of this research, the role of the parent when experimenting with a young child is to instruct the activities and make it possible to do experimenting. The parent instructs the child with questions, requests and with giving them an open invitation. The parents felt that they gave the child room to make observations and to come up with solutions themselves. In the learning occurring at home, where a digital environment supports the interaction between a child and a parent, it is common that the parents' idea of the learning itself and of the aim of the activity dominates the activity done together (Eagle, 2012). A child's possibilities to engage in science activities through a video-based online science club at home depends on whether or not the parents give the child a chance to use the learning environment.

The most significant possibility in video-based online science club was the fact that it is not connected to a specific time or place. Prior researches have highlighted that in traditional non-formal learning environments such as museums, science centers, observatories and zoological parks, one major challenge is their location (Eshach, 2007). Museums and science centers are challenging, since not all have the possibility to visit them, because the distance there is too long. A same kind of a challenge is connected with taking part in children's science clubs. In the interview, the parents brought out that they are not able to offer the child a chance to take part in a science club, because either the distance there is too long or they do not have enough time.

Through the video-based online science club, positive interaction around the scientific contexts was created in homes. Experimenting was seen as pleasant time spent with family. Experiments done at home are a time, when the family discusses, 
jokes around and acts freely together (Solomon, 2003). This kind of a positive atmosphere creates a positive image of science for the child. The instructional videos developed for a learning environment were successful in activating the children towards hands-on working. After the children had watched the instruction video, they were eager to start experimenting in real life. Videos have been seen in prior researches as passive media (Kearny \& Treagust, 2011; Greenfield, 2009) that does not encourage children to experiment or reflect ideas (Hobbs, 2006).

The results showed that the activities of video-based online science club created discussion in the context of science between the child and the parent. Discussion was created with the help of a parent's instruction, but children also returned to discuss and ask about the activities in situations, where the child was faced with the same phenomenon from an activity, but in a different context. Doing activities together was also experienced as having a nice time with the family. According to the parents, a video-based online science club learning environment and the instructional videos did not make the children passive, instead the children were excited to start working with the activity after watching the video.

\section{Implications for further development}

It is beneficial to be taken into consideration in non-formal science activities occurring at home that instructional factor of non-formal learning (Eshach, 2007) is divided instead of only to one target, into two targets, a parent and a child, who both need different kinds of instruction. The instructional factor of non-formal learning consists of the affective and cognitive dimensions (Eshach, 2007), which both should be taken into consideration. video-based online science club are able to give necessary instruction to the child both in the affective and cognitive levels, but a challenge in the video-based online science clubs from the viewpoint of parents is the lacking of the instructional dimension. Instead of seeing the child participating in video-based online science clubs as the learner and the parent as the child's supporter, the parent should be seen in addition as a learner. Therefore, when we speak of young children's non-formal science activities occurring at home, the instructional factor can be divided into two parts: 1) instructional factor from the point of view of a parent and 2) instructional factor from the point of view of a child.

In order for us to be able to support inquiry-based science activities occurring at home, the parent should be offered more detailed instruction on how a specific 
phenomenon should be introduced to the child. In addition, the parent needs conceptual information about the phenomenon and its occurrence in different contexts in the daily life. The affective dimension should be taken into consideration when instructing parents, because the child's chance of participating in non-formal science activities at home is connected to the interest and enthusiasm of parents. The technological issues must be considered in further development of the video-based online science club. Especially, the big file sizes of videos disrupted the sending of reports for the video-based online science club teacher. The application-based mobile solutions should be studied to address that challenge.

\section{References}

Ampartzaki, M., \& Kalogiannakis, M. (2016). Astronomy in Early Childhood Education: A Concept-Based Approach. Early Childhood Education Journal, 44(2), 169-179.

Baram-Tsabari, A., Sethi, R. J., Bry, L., \& Yarden, A. (2006). Using questions sent to an Ask-AScientist site to identify children's interests in science. Science Education, 90(6), 10501072.

Bulunuz, M. (2013). Teaching science through play in kindergarten: Does integrated play and science instruction build understanding? European Early Childhood Education Research Journal, 21(2), 226-249.

Bull, G., \& Kajder, S. (2004). Digital storytelling in the language arts classroom. Learning \& Leading with Technology, 32(4), 46-49.

Burke, L. A., \& Miller, M. K. (2001, May). Phone interviewing as a means of data collection: Lessons learned and practical recommendations. In Forum Qualitative Sozialforschung/Forum: Qualitative Social Research (Vol. 2, No. 2).

Crawford, E. O., Heaton, E. T., Heslop, K., \& Kixmiller, K. (2009). Science Learning at Home Involving Families. YC Young Children, 64(6), 39.

Chaudron, S., M. E. Beutel, M. Černikova, V. Donoso, M. Dreier, B. Fletcher-Watson, A.-S. Heikkilä, et al. 2015. Young Children (o-8) and Digital Technology: A Qualitative Exploratory Study across Seven Countries. Joint Research Centre, European Commission. http://publications.jrc.ec.europa.eu/ repository/handle/JRC93239.

Eagle, S. (2012). Learning in the early years: Social interactions around picture books, puzzles and digital technologies. Computers \& Education, 59(1), 38-49.

Eshach, H., \& Fried, M. (2005). Should science be taught in early childhood? Journal of Science Education and Technology, 14(3), 315-336.

Eshach, H. (2007). Bridging in-school and out-of-school learning: Formal, non-formal, and informal education. Journal of science education and technology, 16(2), 171-190.

Glaser, M., Garsoffky, B., \& Schwan, S. (2009). Narrative-based learning: Possible benefits and problems. Communications, 34(4), 429-447.

Greenfield, P. M. (2009). Technology and informal education: What is taught, what is learned. Science (New York, N.Y.), 323(5910), 69-71.

Guo, Y., Wang, S., Hall, A. H., Breit-Smith, A., \& Busch, J. (2016). The effects of science instruction on young children's vocabulary learning: A research synthesis. Early Childhood Education Journal, 44(4), 359-367. 
Hirsjärvi, S. \& Hurme, H. (2008). Tutkimushaastattelu: teemahaastattelun teoria ja käytäntö. Helsinki: Gaudeamus

Hobbs, R. (2006). Non-optimal uses of video in the classroom. Learning, media and technology, 31(1), 35-50.

Inan, H. Z., \& Inan, T. (2015). 3 H s education: Examining hands-on, heads-on and hearts-on early childhood science education. International Journal of Science Education, 37(12), 19741991.

Kalogiannakis, M., Nirgianaki, G. M., \& Papadakis, S. (2018). Teaching Magnetism to Preschool Children: The Effectiveness of Picture Story Reading. Early Childhood Education Journal, $1-12$.

Kaya, S., \& Lundeen, C. (2010). Capturing parents' individual and institutional interest toward involvement in science education. Journal of Science Teacher Education, 21(7), 825-841.

Kearney, M., \& Treagust, D. F. (2001). Constructivism as a referent in the design and development of a computer program using interactive digital video to enhance learning in physics. Australian Journal of Educational Technology, 17(1), 64-79.

Kim, Y., \& Thayne, J. (2015). Effects of learner-instructor relationship-building strategies in online video instruction. Distance Education, 36(1), 100-114.

Kuhn, D., Black, J., Keselman, A., \& Kaplan, D. (2000). The development of cognitive skills to support inquiry learning. Cognition and Instruction, 18(4), 495-523.

Kumpulainen, K. \& Gillen, J. (2017). Young children's digital literacy practices in the home: A review of the literature. COST ACTION ISI1410 DigiLitEY. University of Sheffield.

Leuchter, M., Saalbach, H., \& Hardy, I. (2014). Designing science learning in the first years of schooling. An intervention study with sequenced learning material on the topic of 'floating and sinking'. International Journal of Science Education, 36(10), 1751-1771.

Maltese, A. V., \& Tai, R. H. (2010). Eyeballs in the fridge: Sources of early interest in science. International Journal of Science Education, 32(5), 669-685.

Mantzicopoulos, P., Patrick, H., \& Samarapungavan, A. (2013). Science literacy in school and home contexts: Kindergarteners' science achievement and motivation. Cognition and Instruction, 31(1), 62-119.

McClure, E. R., Guernsey, L., Clements, D. H., Bales, S. N., Nichols, J., Kendall-Taylor, N., \& Levine, M. H. (2017). STEM Starts Early: Grounding Science, Technology, Engineering, and Math Education in Early Childhood. In Joan Ganz Cooney Center at Sesame Workshop. 1900 Broadway, New York, NY 10023.

Minner, D. D., Levy, A. J., \& Century, J. (2010). Inquiry-based science instruction - what is it and does it matter? Results from a research synthesis years 1984 to 2002. Journal of Research in Science Teaching, 47(4), 474-496.

Nayfeld, I., Brenneman, K., \& Gelman, R. (2011). Science in the classroom: Finding a balance between autonomous exploration and teacher-led instruction in preschool settings. Early Education \& Development, 22(6), 970-988.

Palaiologou, I. (2016). Children under five and digital technologies: implications for early years pedagogy. European Early Childhood Education Research Journal, 24(1), 5-24.

Peterson, S. M., \& French, L. (2008). Supporting young children's explanations through inquiry science in preschool. Early Childhood Research Quarterly, 23(3), 395-408.

Plowman, L., Stephen, C., \& McPake, J. (2010). Supporting young children's learning with technology at home and in preschool. Research Papers in Education, 25(1), 93-113.

Reinhart, M., Bloomquist, D., Strickler-Eppard, L., Czerniak, C. M., Gilbert, A., Kaderavek, J., \& Molitor, S. C. (2016). Taking Science Home: Connecting Schools and Families Through Science Activity Packs for Young Children. School Science and Mathematics, 116(1), 3-16. 
Roberts-Holmes, G. (2014). Playful and creative ICT pedagogical framing: A nursery school case study. Early Child Development and Care, 184(1), 1-14.

Saçkes, M. (2014). How often do early childhood teachers teach science concepts? determinants of the frequency of science teaching in kindergarten. European Early Childhood Education Research Journal, 22(2), 169-184.

Samarapungavan, A., Patrick, H., \& Mantzicopoulos, P. (2011). What kindergarten students learn in inquiry-based science classrooms. Cognition and Instruction, 29(4), 416-470.

Schreier, M. (2014). Chapter 12: Qualitative content analysis. In U. Flick (Ed.), The SAGE handbook of qualitative data analysis (pp. 170-183). London: SAGE Publications

Schäfer, M. S., Füchslin, T., Metag, J., Kristiansen, S., \& Rauchfleisch, A. (2018). The different audiences of science communication: A segmentation analysis of the Swiss population's perceptions of science and their information and media use patterns. Public Understanding of Science, 0963662517752886.

Skoretz, Y. M., \& Cottle, A. E. (2011). Meeting International society for technology in education competencies with a problem-based learning video framework. Computers in the Schools, 28(3), 217-227.

Shymansky, J. A., Yore, L. D., \& Hand, B. M. (2000). Empowering families in hands-on science programs. School Science and Mathematics, 10o(1), 48-58.

Simon, S., Naylor, S., Keogh, B., Maloney, J., \& Downing, B. (2008). Puppets promoting engagement and talk in science. International Journal of Science Education, 30(9), 12291248.

Solomon, J. (2003). Home-school learning of science: The culture of homes, and pupils' difficult border crossing. Journal of Research in Science Teaching, 4O(2), 219-233.

Spektor-Levy, O., Baruch, Y. K., \& Mevarech, Z. (2013). Science and scientific curiosity in preschool - The teacher's point of view. International Journal of Science Education, 35(13), 2226-2253.

Stylianides, A. J., \& Stylianides, G. J. (2011). A type of parental involvement with an isomorphic effect on urban children's mathematics, reading, science, and social studies achievement at kindergarten entry. Urban education, 46(3), 408-425.

Vartiainen, J., \& Aksela, M. (2013). Science clubs for 3 to 6-year-olds: Science with joy of learning and achievement. LUMAT (2013-2015 Issues), 1(3), 315-321.

Yin, R. K. (2009). Case study research: Design and methods (applied social research methods). London and Singapore: Sage.

Young, J., Ortiz, N., \& Young, J. (2017). STEMulating Interest: A Meta-Analysis of the Effects of Out-of-School Time on Student STEM Interest. International Journal of Education in Mathematics, Science and Technology, 5(1), 62-74. 